\title{
Composition and properties of partially hydrolyzed sunflower protein isolates
}

\section{Tamara Nosenko ${ }^{1}$, Valerii Mank ${ }^{1}$, Yaroslava Zhukova ${ }^{2}$, Alyona Cherstva ${ }^{1}$}

\author{
1 - National University of Food Technologies, Kyiv, Ukraine \\ 2 - Institute of Food Resources of National Academy of Agrarian Science of \\ Ukraine, Kyiv, Ukraine
}

Keywords:

Sunflower

Protein

Isolate

Hydrolysis

Proteases

Article history:

Received 24.05.2016

Received in revised

form 14.07.2016

Accepted 01.09.2016

\section{Corresponding \\ author:}

Tamara Nosenko

E-mail:

tnosenko@

yahoo.com

\section{Abstract}

Introduction. Partial enzyme hydrolysis of proteins is common method of modification of their functional properties. The characteristics of partially hydrolyzed proteins obtained from sunflower meal are presented in this work.

Materials and methods. Proteins of sunflower meal were extracted in the presence of two proteases viz. neutral protease and Alkalase during $40 \mathrm{~min}$. Partially hydrolyzed protein samples were prepared by isoelectric precipitation and next drying. The polypeptide composition of protein isolates were studied by polyacrylamide gel electrophoresis, degree of protein hydrolysis, amino acid composition, surface activity and functional properties were estimated.

Results and discussion. The polypeptides of higher molecular weight (45-54 and about 32-35 kDa) were absent in polypeptide profile of partially hydrolyzed proteins either of proteases. At the same time they were abounded with 14$16 \mathrm{kDa}$ polypeptides and polypeptides with molecular weight lower $14 \mathrm{kDa}$.

Partially hydrolyzed protein samples had higher protein content, lower content of ash and carbohydrates as compared with the control sample. The biological value of sunflower protein isolates were limited by three amino acids - sulfur containing amino acids (methionine and cysteine) and lysine. The content of methionine, cysteine and lysine has been increased in protein samples obtained with neutral protease, relative to protein isolate. Differential scanning calorimetric analyze of protein samples have demonstrated that partially hydrolyzed samples contained undenaturated proteins, but their denaturation degree was higher compared with control samples. Partial hydrolysis of sunflower seed proteins have improved their solubility in $\mathrm{pH}$ range from 2 to 8, water holding, oil binding, foaming, emulsifying capacities and surface activity.

Conclusions. Partially hydrolyzed protein samples had higher protein content, lighter color, lower degree of denaturation and better functional properties compared to the traditional protein isolates. 


\section{Introduction}

Partial enzyme hydrolysis of protein is common method of modification of their functional properties. The protein hydrolysates are usually prepared from milk or soy proteins under influence of different proteases. Another source of proteins can be used as substrate for enzyme hydrolysis too. Parrado et al. [1] and Villanueva et al. [2] have obtained sunflower protein hydrolysates from sunflower seed protein isolates, Vioque et al. [3] have produced rape seed protein hydrolysates.

The polypeptide composition of protein isolates have changed as result of protein hydrolysis under different proteases notably polypeptides of smaller size appeared [2, 4]. It was shown that soy and sunflower protein hydrolysates had higher solubility in wide $\mathrm{pH}$ range, in despite of native proteins which have destricted solubility at $\mathrm{pH}$ of isoelectric point $[2,4]$. The pumpkin oil cake globulin hydrolysates obtained with different enzymes (hydrolysis degree 5.6-29.8\%) had also increased solubility within the studied $\mathrm{pH}$ range [5]. In addition, hydrolysates of cucurbitin obtained with Alkalase and pepsin showed antioxidant activity.

In most cases limited protein hydrolysis can improve their emulsifying, foaming properties [3-7] and change sensory characteristics [8].

In our previous works we have shown that extraction of protein from industrial sunflower meal in the presence of trypsin [9] or microbial proteases [10,11] resulted in increase of protein concentration in extracts and protein isolate yield. The protein concentration in extracts obtained in the presence of proteases was approximately twice higher than in control samples. The protein hydrolysis degree was sufficiently low and varied from $3.5 \%$ to $5.2 \%$ at moderate enzyme/substrate ratio and neutral protease [10]. When enzyme:substrate ratio increased the degree of hydrolysis was also rising and reached 9.0-9.5\% during 40-60 $\mathrm{min}$ that is desirable for improvement of protein functional properties, higher hydrolysis level results in loss of protein functionality. The degree of protein hydrolysis varied from 8.5 to $14.5 \%$ when alkaline protease was used at every investigated enzyme:substrate ratio during 40-60 min. It was shown also that correlation $(\mathrm{r}=0.69)$ exists between concentration of proteins in extracts and degree of protein hydrolysis under influence of microbial proteases. The model was obtained for estimation of the affectivity of protein extraction as function of enzyme:substrate ratio and extraction time.

Changes in polypeptide composition of protein isolates under influence of proteases resulted in differences of amino acid composition between unhydrolyzed proteins and proteins partially hydrolyzed by various proteases. Amino acid composition of sunflower meal, protein isolates (PI) and partially hydrolyzed protein isolates (PHPI, hydrolysis degree $12.4 \%$ ) were studied in our previous work [12]. Three amino acids were limiting in sunflower meal proteins almost in equal extent, notably, valine had amino acid score $71.2 \%$ to $\mathrm{FAO} / \mathrm{WHO}$ reference protein, isoleucine -72.5 and lysine $-73.5 \%$, respectively. Amount of amino acids in PI and PHPI had changed comparing with sunflower meal that is content of sulfur containing amino acids and lysine in protein isolates decreased drastically. On the other hand, sunflower protein isolates, obtained by Villanueva et al. [2] and Ivanova et al. [13], were not limited by the content of methionine and cisteine.

In this work we present the next characteristics of partially hydrolyzed proteins (PHPI, hydrolysis degree $8-12 \%$ ), obtained from sunflower meal with assistance of microbial

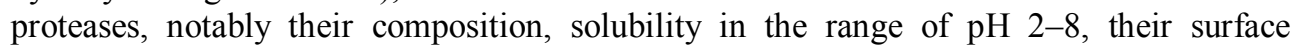
activity, emulsifying, foaming capacities, water and oil binding properties, denaturation temperature and enthalpy of denaturation. 


\section{Materials and methods}

Materials. Sunflower meal was collected from local oil extraction plant, Melitopol, Ukraine. The protein content of meal varied from 33 to $39 \%$. Neutral protease from Bacillus subtilis (Protolad, 70 FIP-U/g, optimum $\mathrm{pH}$ 6.5-7.0, ENZYME, Ukraine) and alkaline protease from Bacillus licheniformis (Alkalase, $2.4 \mathrm{AU} / \mathrm{g}$, optimum $\mathrm{pH}$ 8.5-9.0, ENZYME, Ukraine) were used for hydrolysis. All chemicals used for experiments were at least analytical grade.

Preparation of protein isolate and partially hydrolyzed protein isolates. Proteins were extracted from sunflower meal by sodium chloride solution $(70 \mathrm{~g} / \mathrm{L}, \mathrm{pH} 7.0)$ under constant stirring, at $45^{\circ} \mathrm{C}$ for $40-50 \mathrm{~min}$, meal:solution ratio was $1: 10(\mathrm{w}: \mathrm{v})$.

In order to obtain partly hydrolyzed samples, extraction of proteins from sunflower meal was carried out in the presence of Protolad or Alkalase, with meal:enzyme ratio 100:1. The protease activity was stopped by heating of reaction mixture at $80{ }^{\circ} \mathrm{C}$ for $15 \mathrm{~min}$.

Afterwards, the insoluble residue was precipitated by centrifugation. The supernatant (protein extract) was used for isoelectric protein precipitation at $\mathrm{pH}$ 4.0. After protein coagulation, pellet was separated by centrifugation $(3,000 \mathrm{xg})$, washed with water solution ( $\mathrm{pH}$ adjusted with $\mathrm{HCl}$ to 4.0 ), protein pellet was collected and dried to $6-8 \%$ humidity.

Determination of the Protein Hydrolysis Degree. The degree of protein hydrolysis (DH) was determined according to Popovic et al. [5] in some modification. To a $0.5-\mathrm{mL}$ aliquot of the supernatant obtained after hydrolysis, an equal volume of $0.5 \mathrm{~mol} / \mathrm{dm}^{3} 3-$ chloro-acetic acid (TCA) was added. The mixture was incubated for $30 \mathrm{~min}$ at $4{ }^{\circ} \mathrm{C}$. Thereafter, the mixture was centrifuged at $7000 \mathrm{rpm}$ for $10 \mathrm{~min}$. The TCA-soluble fractions were analyzed to determine the protein content by the method of Lowry et al. [15]. The DH value was calculated as the increase of TCA-soluble protein concentration in the presence of protease $\left(\mathrm{C}_{\text {protease }}\right)$ to protein content in control samples $\left(\mathrm{C}_{\text {control }}\right)$, expressed as a percentage:

$$
D H=\frac{C_{\text {protease }}-C_{\text {control }}}{C_{\text {control }}} \times 100
$$

Analysis of protein sample composition. Moisture and ash content of protein samples was determined using the gravimetric method. Oil content was measured according to Soxhlet's method. For this purpose $5 \mathrm{~g}$ of sample were extracted for $24 \mathrm{hrs}$ using hexane as a solvent. Crude protein (Nx6.25) was determined by the Kjeldahl method according to AOAC Method [16]. Crude protein content was calculated with a conversion factor of 6.25. Carbohydrate content was calculated as difference between dry substances mass and mass of protein, ash and oil.

Determination of amino acid composition of protein samples. The direct acid hydrolysis of protein isolates was used to obtain hydrolysates suitable for determination of all amino acids except cysteine and tryptophan. Hydrolysis was carried out in test tubes by adding of $1 \mathrm{~mL}$ of $6 \mathrm{M} \mathrm{HCl}$ to dry sample, corresponding to $2 \mathrm{mg}$ of protein. The mixture was frozen in a bath at $-80{ }^{\circ} \mathrm{C}$, evacuated, sealed and then samples were exposed at $106^{\circ} \mathrm{C}$ for $24 \mathrm{~h}$ in a thermostat. After hydrolysis samples were cooled and $\mathrm{HCl}$ was removed from them by evacuating in dessicator containing $\mathrm{NaOH}$ pellet. After drying of samples $4 \mathrm{~mL}$ of deionized water was added and drying procedure was repeated. Dry samples were dissolved in citrate buffers $(0.3 \mathrm{M} / \mathrm{L}, \mathrm{pH} 2.2)$ and used for amino acid analyses. 
Amino acid analyzer T 339 (Czech Republic) was used for amino acid content analysis. Standard amino acid mixture containing $0.5 \mu \mathrm{M}$ of the 17 commonly occurring amino acid was used to calculate the amount of amino acids in the samples.

Sodium Dodecyl Sulfate Polyacrylamide Gel Electrophoresis (SDS-PAGE). The polypeptide composition of the protein samples were analyzed by sodium dodecyl sulfate polyacrylamide gel electrophoresis by the method of Laemmli [17]. The gel system, containing $0.2 \%(\mathrm{wt} / \mathrm{vol})$ SDS consisted of a $12 \%$ polyacrylamide-resolving gel ( $\mathrm{pH} 8.8)$ and a $4 \%$ stacking gel (pH 6.8 ) in a minislabs system (Bio-Rad Mini-Protean II Model). The length of the resolving and stacking gel were 10 and $2 \mathrm{~cm}$, respectively, with a gel thickness of $0.75 \mathrm{~mm}$. Electrophoresis was perfomed at a constant current of $25 \mathrm{~mA}$. Protein bands were stained by immersion of the gel in $0.05 \%$ Coomassie brilliant blue G250 solution, in $45 \%$ methanol and $9 \%$ acetic solution.

Protein molecular weights were estimated using low MW markers (Pharmacia, Amersham, England) that included phosphorylase b $(94,000)$, albumin $(67,000)$, ovalbumin $(43,000)$, carbonic anhydrase $(30,000)$, trypsin inhibitor $(20,100)$, and a-lactalbumin $(14,400)$.

Differential scanning calorymetry (DSC). Thermal denaturation of the protein suspensions was studied by DSC with a DSC Q 2000 calorimeter (V24.4 Build 116, TA Instruments, Germany). $8 \mathrm{mg}$ of sample was placed in an aluminium pan and heated from 20 to $110^{\circ} \mathrm{C}$ at a rate of $2{ }^{\circ} \mathrm{C} / \mathrm{min}$.

Determination of protein solubility. Determination of solubility was made in a $\mathrm{pH}$ region of 2.0 to 8.0 adjusted by $0.1 \mathrm{M} \mathrm{HCl}$ or $\mathrm{NaOH}$. Protein samples were dissolved for 1 $\mathrm{h}$ at room temperature at concentration $1 \% \mathrm{wt} / \mathrm{vol}$ under constant stirring. Suspensions were centrifuged at 3,000 x $g$ for $20 \mathrm{~min}$. Protein concentration in supernatants were measured by method of Lowry et al. [15]. Solubility was expressed as grams of soluble protein/100 grams of sample.

Determination of protein sample functional properties. The water holding capacities (WHC) of proteins were measured as described by Ashraf et al. [18] taking $1 \mathrm{~g}$ of protein extract and resuspended in $10 \mathrm{~mL}$ of distilled water and mixed vigorously for $2 \mathrm{~min}$, the supernatants obtained after centrifugation at $3,000 \mathrm{x}$ g for $20 \mathrm{~min}$ were decanted and the weights of the sediments were determined, the WHC values expressed as gram of water absorbed per $100 \mathrm{~g}$ of protein.

The oil binding capacities (OBCs) of seed proteins were measured using the method of Ashraf et al. [18] taking $1 \mathrm{~g}$ of protein, deposited and reweighed in $50 \mathrm{~mL}$ centrifuge tubes and thoroughly mixed for $3 \mathrm{~min}$ with $10 \mathrm{~mL}$ of vegetable oil. Samples were allowed to stand for $30 \mathrm{~min}$ and the mixtures were centrifuged at 3,000 x g for $20 \mathrm{~min}$, the supernatants were carefully poured immediately after centrifugation and tubes with the sediments were weighted. The OBC values expressed as gram of oil absorbed per $100 \mathrm{~g}$ of protein isolates.

The emulsifying capacity (EC) of the protein samples were determined according to Karki et al. [19] taking $8.5 \mathrm{~g}$ of each sample and mixed with $50 \mathrm{~mL}$ of distilled water for 2 min using a blender and vegetable oil was adding slowly with continuous blending. The process was stopped after every 2 min to check for emulsion breakage. The maximum volumes of oil that was emulsified were measured and emulsifying capacity was determined as volume of oil relatively to $1 \mathrm{~g}$ of protein isolates.

The foaming capacity (FC) of the protein samples were determined according to Makri et al. [20] taking $1 \%$ of the samples and resuspended in deionized water, $\mathrm{pH}$ was adjusted 
to 7.4 with $0.1 \mathrm{M} \mathrm{NaOH}$ and $0.1 \mathrm{M} \mathrm{HCl} .100 \mathrm{~mL}$ of solution were blended for 3 minutes and poured into a $500 \mathrm{~mL}$ graduated cylinder. The volume of foam $\left(\mathrm{V}_{\mathrm{f}}\right)$ and liquid $\left(\mathrm{V}_{\mathrm{l}}\right)$ were immediately recorded and FC was calculated using the following equation:

$$
\mathrm{FC}=\frac{V_{f}}{V_{l}} \cdot 100
$$

Surface tension measurements. Series of protein suspensions with concentrations from 0.03 to $0.5 \%(\mathrm{w} / \mathrm{v})$ were prepared in water solution at $\mathrm{pH} 8.0$ adjusted with $0.1 \mathrm{M}$ $\mathrm{NaOH}$. The surface tension measurements were made with a stalagmometer. Three readings were made on each sample to obtain an average value. All measurements were made at temperature $(20 \pm 1){ }^{\circ} \mathrm{C}$. Distilled water was used as surface-tension standard. The surface tension of protein suspensions was calculated using the following equation:

$$
\sigma=\sigma_{0} \frac{\rho \times \mathrm{N}_{0}}{\rho_{0} \times \mathrm{N}}
$$

where $\sigma_{0}, \rho_{0}$ and $\mathrm{N}_{0}$ are the surface tension, density and drop number of distilled water; $\rho$ and $\mathrm{N}$ are the surface tension, density and drop number of protein suspension respectively.

Statistical analysis. Data were expressed as means \pm standard deviations for triplicate determination. Statistical analysis was performed using Microsoft Excel 2007. Differences were considered to be significant at validity of $\alpha=0.95$.

\section{Results and discussion}

Chemical and polypeptide composition of sunflower seed isolated proteins. The sunflower seed protein isolate used as a control sample had a protein content about $78 \%$ and high carbohydrate content (Table 1). Partially hydrolyzed protein sample obtained with neutral protease (hydrolysis degree $8.5 \%$ ) contained about $90 \%$ proteins, lower amount of ash and more than two times less of carbohydrates than protein isolates. The protein sample obtained with Alkalase (hydrolysis degree 11.5\%) also had higher protein content, lower content of ash and carbohydrates as compared with the control sample. Such influence of partial protein hydrolysis on the chemical composition of protein samples is obviously due to decrease of intermolecular aggregation of smaller polypeptides with other components of sunflower seed including carbohydrates. Low amount of concomitant substances are coprecipitated from the protein suspension together with small polypeptides at their isoelectric precipitation. And finally partial hydrolysis could result in readsorption of some contaminations from the protein surface.

Using of Protolad and Alkalase at extraction of proteins from sunflower meal resulted in changes of polypeptides composition of obtained partially hydrolyzed proteins (Figure 1).

Table 1

Chemical composition of sunflower seed proteins calculated on a dry weight basis

\begin{tabular}{|l|c|c|c|}
\hline Component & $\begin{array}{c}\text { Protein } \\
\text { isolate }\end{array}$ & $\begin{array}{c}\text { Partially hydrolyzed } \\
\text { proteins (Protolad) }\end{array}$ & $\begin{array}{c}\text { Partially hydrolyzed } \\
\text { proteins (Alkalase) }\end{array}$ \\
\hline Protein & $78.4 \pm 0.5$ & $89.5 \pm 0.4$ & $87.2 \pm 0.6$ \\
\hline Ash & $4.9 \pm 0.2$ & $2.8 \pm 0.1$ & $3.0 \pm 0.2$ \\
\hline Carbohydrate & $16.0 \pm 0.4$ & $7.2 \pm 0.3$ & $9.2 \pm 0.4$ \\
\hline Lipid & $0.7 \pm 0.1$ & $0.5 \pm 0.1$ & $0.6 \pm 0.1$ \\
\hline
\end{tabular}




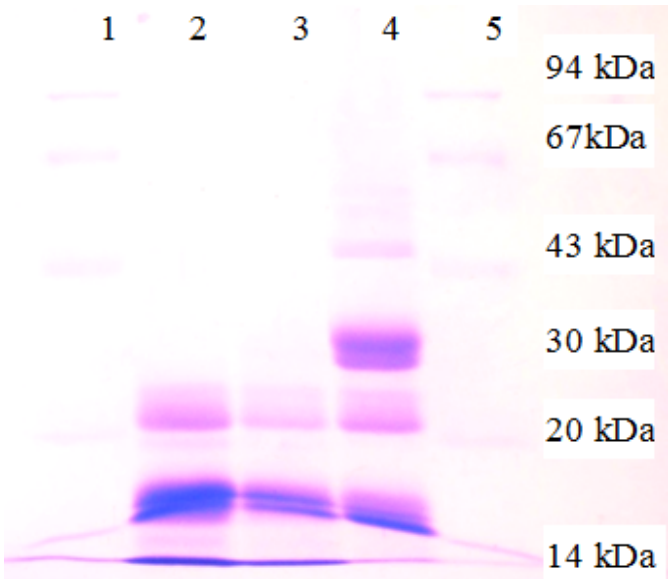

Figure 1. Sodium dodecyl sulfate-polyacrilamide gel electrophores polypeptides profile of sunflower seed proteins isolate (lane 4), partially hydrolyzed by Protolad (lane 2) and Alkalase (lane 3), lane 1 and 5 - molecular weight markers $(94,67,43,30,20$ та 14 kDa).

The polypeptides of higher molecular weight (45-54 and about 32-35 kDa) were absent in polypeptide profile of proteins partially hydrolyzed by either of proteases. They abounded with 14-16 kDa polypeptides and polypeptides with molecular weight lower 14 $\mathrm{kDa}$. Some new polypeptides with molecular weight in rage of 10-20 $\mathrm{kDa}$ had appeared in their profiles, whereas control protein sample had relatively high content of $32-35 \mathrm{kDa}$ polypeptides and low content of $16 \mathrm{kDa}$ polypeptides.

The essential amino acid compositions of protein samples were sufficient different, indicating that limited hydrolysis of sunflower meal proteins under their extraction have changed the biological value of proteins (Figure 2). The biological value of sunflower protein isolate was limited by three amino acids - sulfur containing amino acids (methionine and cysteine), their content was only about $46 \%$ of FAO protein, and lysine which was $54 \%$ of references protein. Since content methionine and cysteine in sunflower meal proteins was $80 \%$ of FAO proteins [12] evidently, that proteins abounded by these hydrophobic amino acids are less soluble and are not extractable from the meal. Content of other essential amino acids exceeds their content in references protein. Limited hydrolysis of sunflower meal proteins by Protolad have increased amino acid score of every essential amino acid compared to the protein isolate, most significantly leucine, sum of aromatic amino acids and valine. This protein samples have increased content of methionine and cysteine by $26 \%$ and lysine - by $17 \%$ relative to protein isolate. On the contrary, essential amino acids content of protein samples limited hydrolyzed by Alkalase were lower compared to the protein isolate, these proteins were especially poor in sulfur containing amino acids (their content was only $23 \%$ relative to FAO pattern). This phenomenon could be due to loss of such amino acids with hydrolysis products which are not precipitated during isoelectric precipitation. Decrease of methionine and cysteine content were observed also in sunflower hydrolysate obtained with Alkalase [2]. 


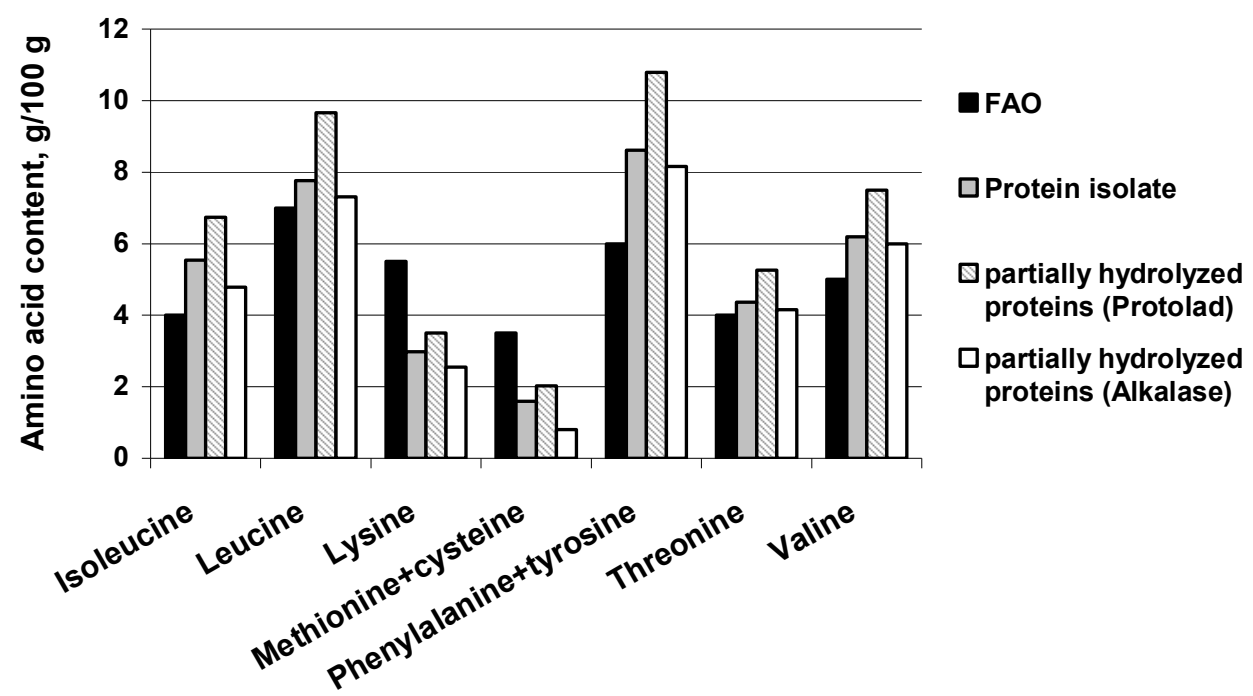

Figure 2. Essential amino acid composition of sunflower seed protein samples

Protein denaturation degree of sunflower protein isolates. Obtained protein samples had similar denaturation temperatures and enthalpies (Table 2, Figure 3). Dependences of thermal flow of protein suspensions from temperature were similar for partially hydrolyzed and unhydrolyzed protein samples (Figure 3). The denaturation temperatures of protein isolate was about $85{ }^{\circ} \mathrm{C}$. Proteins of partially hydrolyzed samples had a little lower temperature stability, the denaturation temperature were 80.2 and $79.1{ }^{\circ} \mathrm{C}$ for partially hydrolyzed proteins by Protolad and Alkalasa respectively. Denaturation degree of partially hydrolyzed proteins were higher compared to the protein isolate, enthalpies of denaturation were 151.5 and $146.8 \mathrm{~J} / \mathrm{g}$ proteins for Protolad and Alkalasa sample respectively. Thus, in spite of limited hydrolysis, protein samples obtained with proteases, contains macromolecules with preserved second and tertiary structure.

Denaturation temperature and enthalpies of sunflower protein products

\begin{tabular}{|l|c|c|}
\hline Sunflower protein products & $\begin{array}{c}\text { Denaturation } \\
\text { temperature, }{ }^{\circ} \mathbf{C}\end{array}$ & $\begin{array}{c}\text { Enthalpy, } \\
(\Delta \mathbf{H}, \mathbf{J} / \mathbf{g} \text { protein })\end{array}$ \\
\hline Protein isolate & $84.9 \pm 1.7$ & $184.7 \pm 2.1$ \\
\hline $\begin{array}{l}\text { Partially hydrolyzed proteins } \\
\text { (Protolad) }\end{array}$ & $80.2 \pm 1.5$ & $151.5 \pm 1.6$ \\
\hline $\begin{array}{l}\text { Partially hydrolyzed proteins } \\
\text { (Alkalase) }\end{array}$ & $79.1 \pm 1.2$ & $146.8 \pm 1.4$ \\
\hline
\end{tabular}




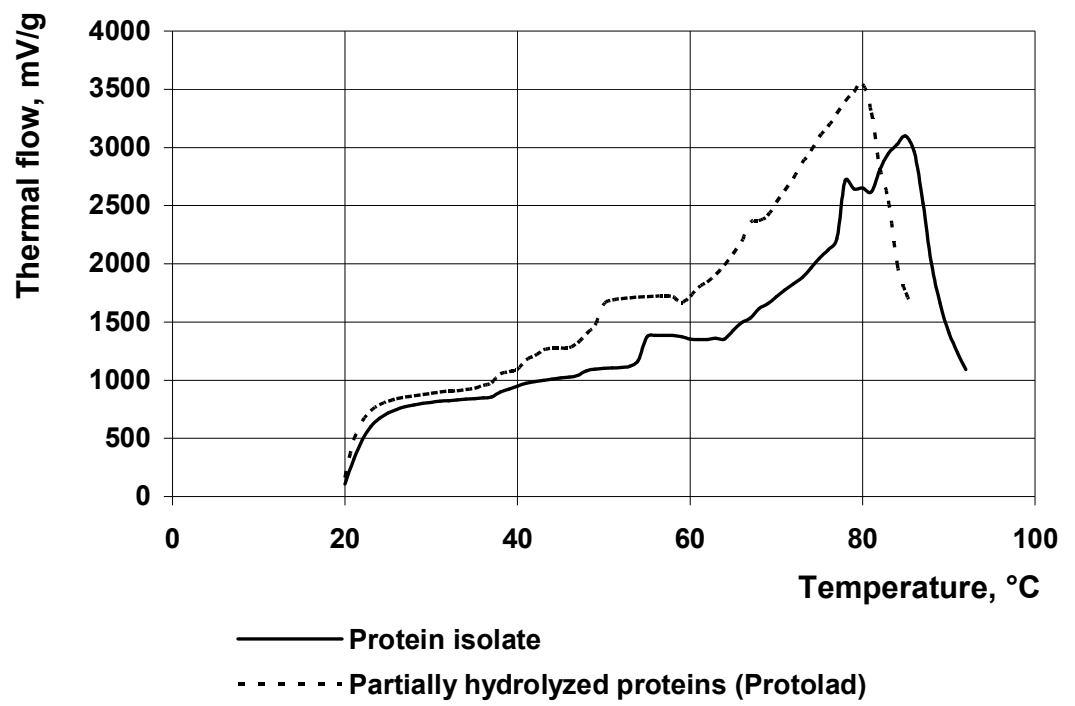

Figure 3. Dependence of protein suspensions thermal flow from temperature.

Solubility of protein samples and their functional properties. High solubility of isolated proteins is required in many foods because of soluble proteins provide a homogeneous dispersability of molecules in colloidal systems and many other functional properties of proteins are realized when they are in soluble state. The solubility of proteins usually increased over a wide range of $\mathrm{pH}$ as result of their hydrolysis [14]. Indeed, protein samples, containing limited hydrolyzed polypeptides, had higher solubility in $\mathrm{pH}$ range from 2 to 8 (Figure 4).

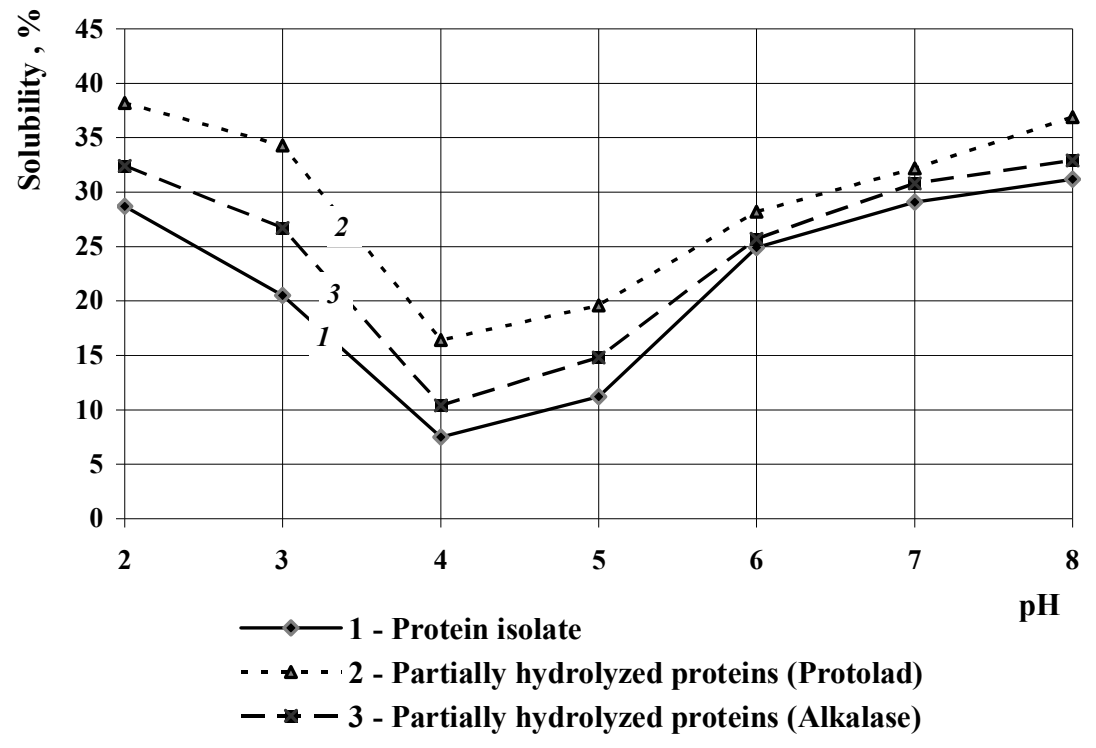

Figure 4. Solubility of sunflower protein samples at different $\mathrm{pH}$ values 
The greatest increase of solubility was observed at acid medium $(\mathrm{pH} \mathrm{2-5)} \mathrm{for} \mathrm{protein}$ sample, partially hydrolyzed by Protolad, solubility differences between samples decreased at $\mathrm{pH}$ 6-8. Increase of solubility for protein sample, partially hydrolyzed by Alkalase, was insignificant at $\mathrm{pH}$ range $2-5$ and very poor at higher $\mathrm{pH}$, that could be determined not only specific effect of this protease and properties of hydrolysis products, but also composition of proteins which were extracted in alkaline solution.

Accordingly, the water holding capacity of partially hydrolyzed protein samples increased too (Figure5, a), for protein sample, partially hydrolyzed by Protolad, this increase was almost five times, for protein sample, partially hydrolyzed by Alkalase, this characteristic improved four times. The increase of oil binding capacities was statistically insignificant for both partially hydrolyzed protein samples.

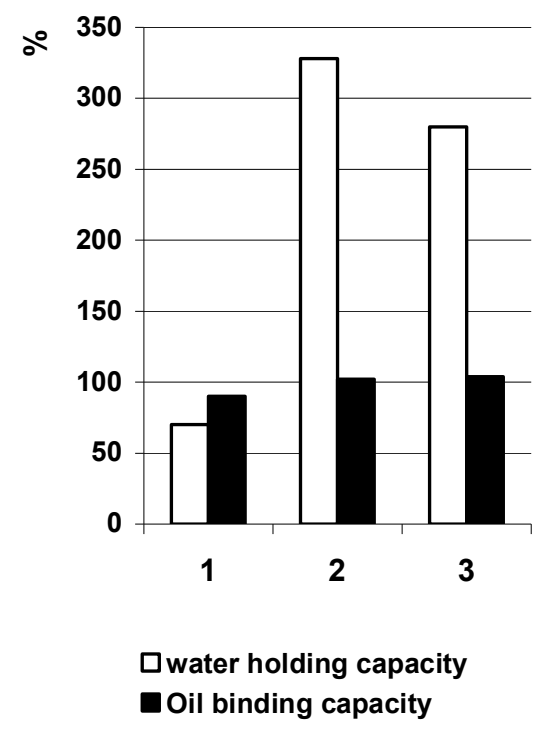

$a$

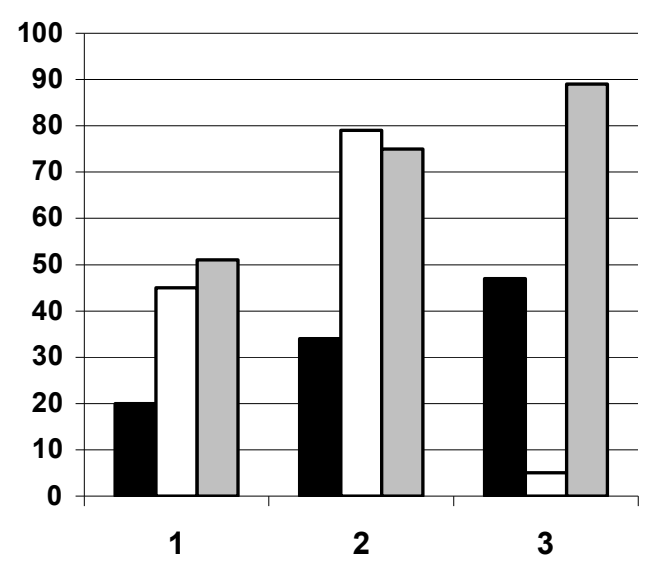

Foam capacity, cm/g 口Foam stability, \% 口Emulsifying capacity, $\mathrm{ml} / \mathrm{g}$

$b$

Figure 5. Functional properties of sunflower protein samples: 1 - protein isolate, 2 - partially hydrolyzed proteins (Protolad), 3 - partially hydrolyzed proteins (Alkalase).

Isolated proteins have surface activities and hence are active in creation of such disperse systems as foams and emulsions. Dependences of surface tension of protein suspensions from their concentration have demonstrated that interfacial properties partially hydrolyzed proteins have been improved under influence of limited hydrolysis (Figure 6). The surface activity of protein sample, partially hydrolyzed by Protolad, has increased most drastically, even at very low protein concentrations $(<0.1 \%)$ surface tension coefficient decreased about $10 \%$ compared to the protein isolate.

Foaming and emulsifying capacities partially hydrolyzed proteins increased substantially (Figure 5, b). Foaming and emulsifying capacities were higher in sample, partially hydrolyzed by Alkalase, but foam stability of this sample was very poor. At the same time foam stability was highest in the sample, partially hydrolyzed by Protolad. Loss of foaming stabilizing capacity with increase of hydrolysis degree had been demonstrated for soy proteins too [4]. 


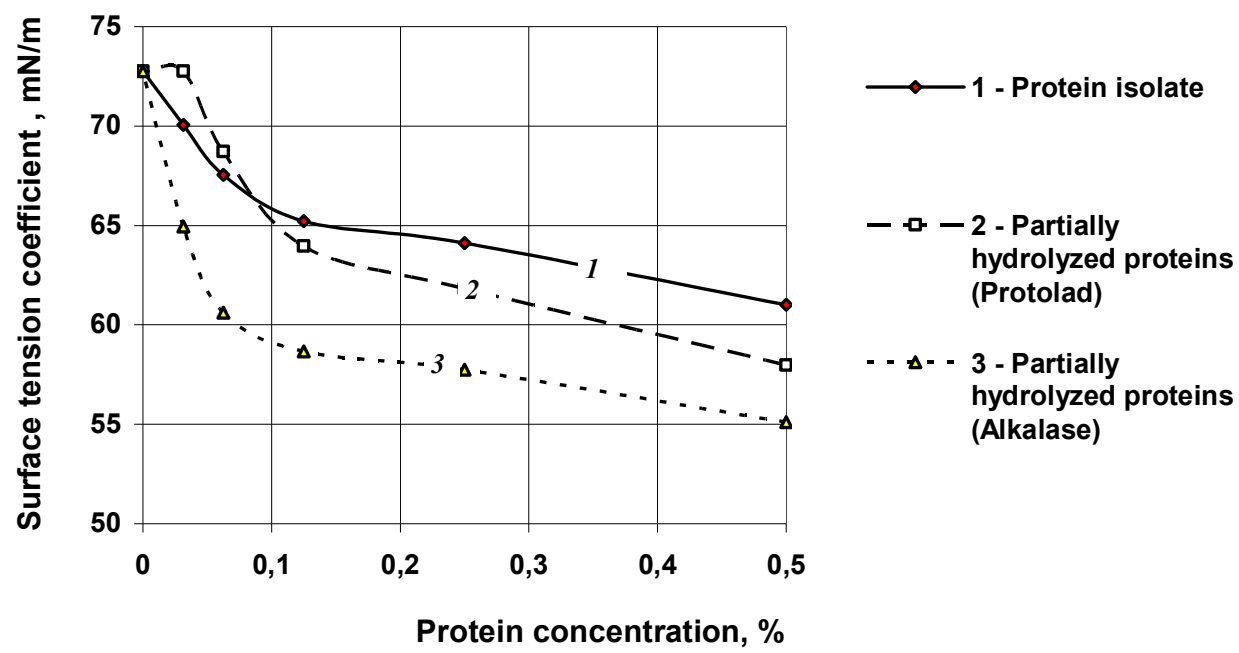

Figure 6. Dependence of surface tension coefficient of protein suspensions from their concentration.

\section{Conclusion}

We have used two proteases during extraction of proteins from sunflower seed meal. We have obtained the partially hydrolyzed protein samples with different composition, color, denaturation degree and functional properties. These samples had higher protein content compared to the traditional protein isolates, protein sample partially hydrolyzed by neutral protease had higher biological value too. Protein solubility at $\mathrm{pH} 2-8$, water holding, oil binding, foaming and emulsifying capacities of partially hydrolyzed protein samples were improved compared to the control.

\section{Acknowledgements}

The authors would like to thank Dr. Valeriy Davidenko (Institute of Macromolecular Chemistry of National Academy of Science of Ukraine) for his assistance in differential scanning calorimetric measurements.

\section{References}

1. Parrado J., Bautista J., Machado A. (1991), Production of Soluble Enzymatic Protein Hydrolysate from Industrially Defatted Nondehulled Sunflower Meal, J. Agr. Food. Chem., 39(3), pp. 447-450.

2. Villanueva A., Vioque J., Sánchez-Vioque R., Clemente A., Pedroche J., Bautista J., et al. (1999), Peptide characteristics of sunflower protein hydrolysates, J. Am. Oil. Chem. Soc., 76(12), pp. 1455-1460. 
3. Vioque J., Sanchez-vioque R., Clements A., Pedroche J., Millan F. (2000), Partially hydrolyzed rapeseed protein isolates with improved functional properties, J. Am. Oil. Chem. Soc., 77(4), pp. 447-450.

4. Molina Ortiz S.E., An M.C. (2000), Analysis of products, mechanisms of reaction, and some functional properties of soy protein hydrolysates, J. Am. Oil. Chem. Soc., 77(12), pp. 1293-1301.

5. Popović L., Peričin D., Vaštag Ž, Popovic S, Krimer V, Torbica A. (2013), Antioxidative and Functional Properties of Pumpkin Oil Cake Globulin Hydrolysates, J. Am. Oil. Chem. Soc., 90(8), pp. 1157-1165.

6. Krinstinsson H, Rasco B. (2000), Biochemical and functional properties of Atlantic salmon muscle proteins hydrolyzed with various alkaline proteases, J. Agr. Food. Chem., 48(3), pp. 657-666.

7. Chabanon G., Chevalot I., Framboisier X., Chenu S., Marc I. (2007), Hydrolysis of rapeseed protein isolates, pp. kinetics, characterization and functional properties of rapeseed hydrolysates, Process Biochem, 42(10), pp. 1419-1428.

8. Lamsal B.P., Reitmeier C., Murphy P.A., Jonson L.A. (2006), Enzymatic hydrolysis of extruded-expelled soy flour and resulting functional properties, J. Am. Oil. Chem. Soc., 83(8), pp. 731-737.

9. Nosenko T.T. (2012), Protein isolate obtaining from sunflower meal with proteolytic enzyme, Scientific works of National university of food technologies, 47, pp. 96-101 (in Ukrainian).

10. Nosenko T, Kubaychuk O, Vovkodav N, Cherstva A. (2014), Influence of partial hydrolysis on the protein extraction from Sunflower meal, Ukrainian Journal of Food Science, 2(2), pp. 244-252.

11. Nosenko T.T., Zhukova Y., Cherstva A. (2015), Sunflower protein hydrolysis degree by proteases, Scientific works of University of Food Technologies, LXII, pp. 64-67.

12. Nosenko T.T. (2014), Comparable evaluation of amino acid composition of sunflower protein isolates, Journal of Food and Packaging Science, Technique and Technologies, 2(4), pp. 36-39.

13. Ivanova P., Chalova V., Koleva L., Pishtiyski I. (2013), Amino acid composition and solubility of proteins isolated from sunflower meal produced in Bulgaria, Int. Food. Res. J., 20(6), pp. 2995-3000.

14. Mahmoud M.I. (1994), Physicochemical and Functional Properties of Protein Hydrolysates in Nutritional Products, Food Technol-Chicago, 48, pp. 89-95.

15. Lowry O., Rosenbrough N., Fair A., Randall R. (1951), Protein measurement with the Folin-phenol reagent, J Biol Chem., 193, pp. 265-275.

16. (1990), AOAC Official Methods of Analysis, 15th edn., Assotiation of Official Analytical Chemists, Arlington, hh.1-11, Method Aa 5-38.

17. Laemmli U. K. (1970), Cleavage of Structural Proteins During Assembly of the Head of Bacteriophage T4, Nature, 227, pp. 680-685.

18. Ashraf S., Saeed S.M.G., Sayeed S.A., Ali R. (2012), Impact of microwave treatment on the functionality of cereals and legumes, Int. J. Agr. Biol., 14(3), pp. 365-370.

19. Karki B., Lamsal B.P., Grewell D., Pometto A.L., Leeuwen J., Khanal S.K. et al. (2009), Functional properties of soy protein isolates produced from ultrasonicated defatted soy flakes, J. Am. Oil. Chem. Soc., 86(10), pp. 1021-1028.

20. Makri E., Papalamprou E., Doxastakis G. (2005), Study of functional properties of seed storage proteins from indigenous European legume crops (lupin, pea \& broad bean) in admixture with polysaccharides, Food Hydrocolloid, 19(3), pp. 583-594. 